\title{
PHENOTYPIC PLASTICITY OF WALL ULTRASTRUCTURE IN THE GREEN ALGA PEDIASTRUM S.L. (CHLOROPHYTA, SPHAEROPLEALES)
}

\author{
JOANNA LENARCZYK ${ }^{1} \&$ KONRAD WOlOWSKI
}

\begin{abstract}
This study examined wall ultrastructure variability in the microscopic green alga Pediastrum s.1. Its value as a diagnostic character is discussed. Field and cultured material of 21 taxa were compared using light and scanning electron microscopy. Nine ultrastructural elements occurring on the surface of Pediastrum are documented with LM and SEM micrographs. The highest number of taxa showed reticulate ornamentation composed of a trigonal mesh and granules situated on its corners. The paper considers the use of wall ultrastructure to reconcile traditional and modern taxonomical systems with regard to Pediastrum varieties, and addresses the phylogenetic relationships between strains representing different varieties.
\end{abstract}

Key words: cell wall patterns, green algae, Pediastrum, scanning electron microscopy, taxonomy, ultrastructure

Joanna Lenarczyk \& Konrad Wolowski, Department of Phycology, W. Szafer Institute of Botany, Polish Academy of Sciences, Lubicz 46, 31-512 Kraków, Poland; e-mail: j.lenarczyk@botany.pl

\section{INTRODUCTION}

Pediastrum Meyen (Chlorophyceae, Sphaeropleales) is currently recognized as containing 46 taxa belonging to 27 species (Buchheim et al. 2005; Lenarczyk 2014). Although the genus itself is cosmopolitan, only a few species such as Pediastrum boryanum (Turpin) Menegh. and $P$. duplex Meyen occur worldwide (Komárek \& Jankovská 2001). Other species such as P. privum (Printz) E. Hegewald (Kowalska \& Wołowski 2010a; Lang et al. 2012) are less common. Taxa of the genus form distinctive flat aggregations of cells (coenobia) as a disc-like structure usually composed of 16 , 32 or 64 individual cells. Species and infraspecific taxa are distinguished mainly by the shape of marginal cells, including their lobes and processes, incisions between the lobes, and wall surface ornamentation. The latter character usually requires observation by scanning electron microscopy.

A broad study of wall structure in Pediastrum was published by Parra (1979), who introduced terminology for ultrastructure and ornamentation

\footnotetext{
1 Corresponding author
}

types. That work examined 11 species from field, cultured and herbarium material, originating mainly from Europe (e.g., Germany, France, Sweden) and also from other continents including Asia and North and South America. Parra concluded that cell wall ornamentation is an important character for distinguishing taxa on the infraspecific level. This opinion was supported by Wu (1987), who revised taxa from Taiwan and documented them with SEM micrographs. However, in a study of granule density on the cell wall surface in cultured P. boryanum, Nielsen (2000) concluded that those structures alone cannot be used as characters for diagnosing infraspecific taxa. Wall ultrastructure in Pediastrum has also been analyzed in taxonomic work by Couté and Tell (1979), Hegewald and Yamagishi (1994), An et al. (1999), Hegewald and Jeon (2000), McManus and Lewis (2011) and others.

Wall ultrastructure has been treated in studies of the formation of the coenobium and cell wall (Gawlik \& Millington 1969; Millington \& Gawlik 1970; Marchant 1974; Millington et al. 1981), and more recently in research on phylogenetic 
relationships (Buchheim et al. 2005; McManus \& Lewis 2005, 2011; Jena et al. 2014).

The aim of the present study was to determine the variability of wall ultrastructure in Pediastrum taxa observed in field and cultured material from various waterbodies in Poland, and to consider these findings in the context of a practical taxonomical identification system.

\section{MATERIAL AND METHODS}

Inland water samples containing Pediastrum were collected in summer 2008 and 2009 from 48 water bodies in lowland and upland regions of Poland, and in summer 2011 from Wyżni Czerwony Stawek lake in the Tatra Mountains (Table 1). Additional water samples from Jezioro Warnowskie lake and Jezioro Zatorek lake used to initiate some of the Pediastrum cultures were obtained in 2008 (Table 2). The samples were taken with a plankton net from 1 or 2 localities of each waterbody. The material from each locality was preserved with 2-4\% formaldehyde, except for three samples $(3,5,8)$ collected in 2009 (Table 1), which were preserved with $1-2 \%$ glutaraldehyde in cacodylate buffer in order to apply the protocol for preparing samples for scanning electron microscopy (SEM) with critical-point drying. Additionally, material from six localities (asterisked in Table 1) was kept alive for culturing.

Fourteen monoclonal cultures were started with single Pediastrum coenobia transferred with a Narishige MM 188 micromanipulator into sterile liquid medium (Table 2). The media used were Chu's medium (Parra 1979), a mixture of Chu's and Knop's media (Starmach 1963), and $\mathrm{L}-\mathrm{S}_{2} \mathrm{~T}_{2}$, for which a recipe was available at the website of the ACOI Coimbra Collection of Algae [http://acoi.ci.uc.pt/]. The strains were cultured in a Bolarus G-18-2 phytotron at $c a 22^{\circ} \mathrm{C}$ under fluorescent tubes in the Phycological Laboratory of the W. Szafer Institute of Botany, Polish Academy of Sciences, Kraków.

Wall patterns were observed in preserved field material (Table 1) and living isolates (Table 2) by both light (LM) and scanning electron microscopy (SEM). LM studies employed Nikon OPTIPHOT-2, Jenaval (Carl Zeiss) and Nikon Eclipse 600 microscopes. For SEM the material was prepared and analyzed in two ways. The material preserved with formaldehyde and the living isolates were first rinsed with distilled water, then placed on cover glasses and air-dried at $c a 35^{\circ} \mathrm{C}$. The cover glasses were affixed to aluminum stubs with doublesided carbon type. The material preserved with glutar-

$\begin{array}{lllllllllll}0.0 & 0.1 & 0.2 & 0.3 & 0.4 & 0.5 & 0.6 & 0.7 & 0.8 & 0.9 & 1.0\end{array}$
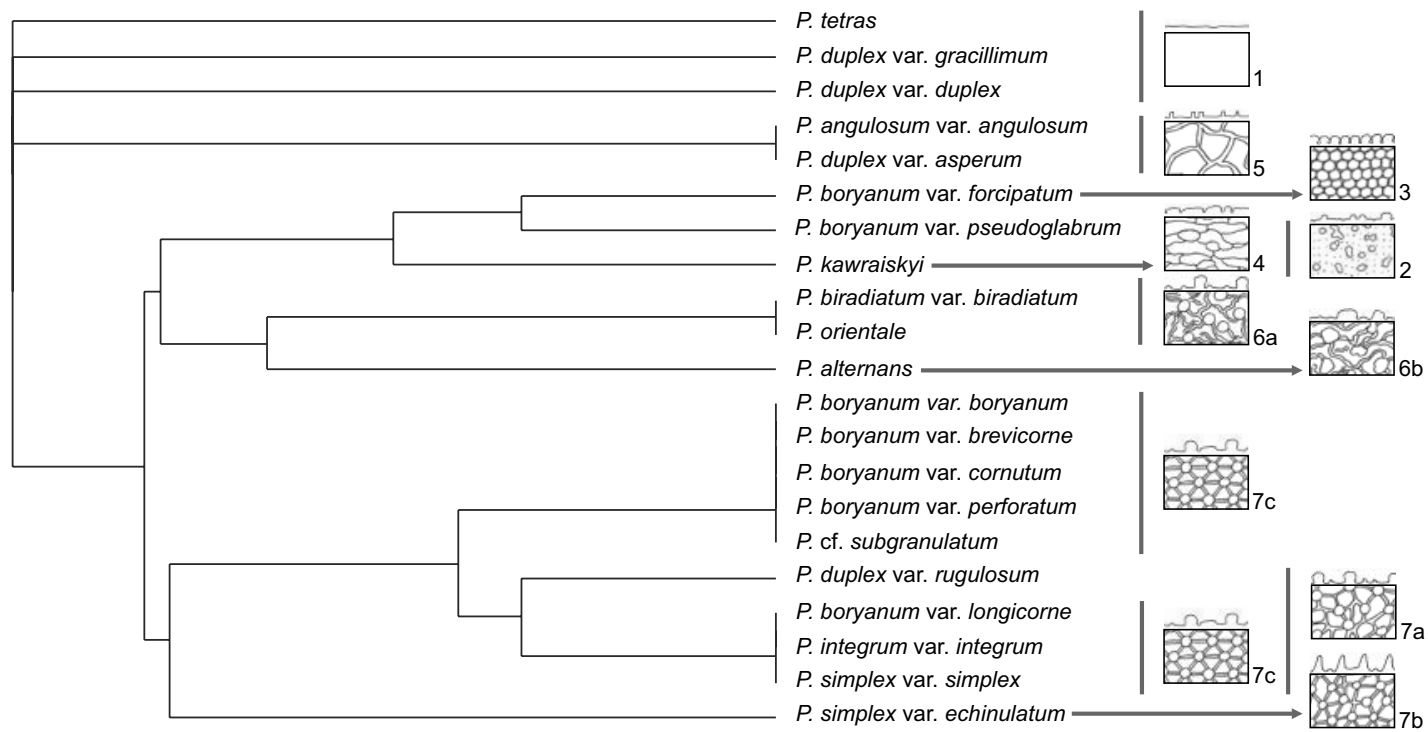

Fig. 1. Similarities between wall patterns in Pediastrum, based on Jaccard's coefficient and UPGMA clustering. For numbers of types of wall patterns see Table 4. Drawings after Lenarczyk (2014). 


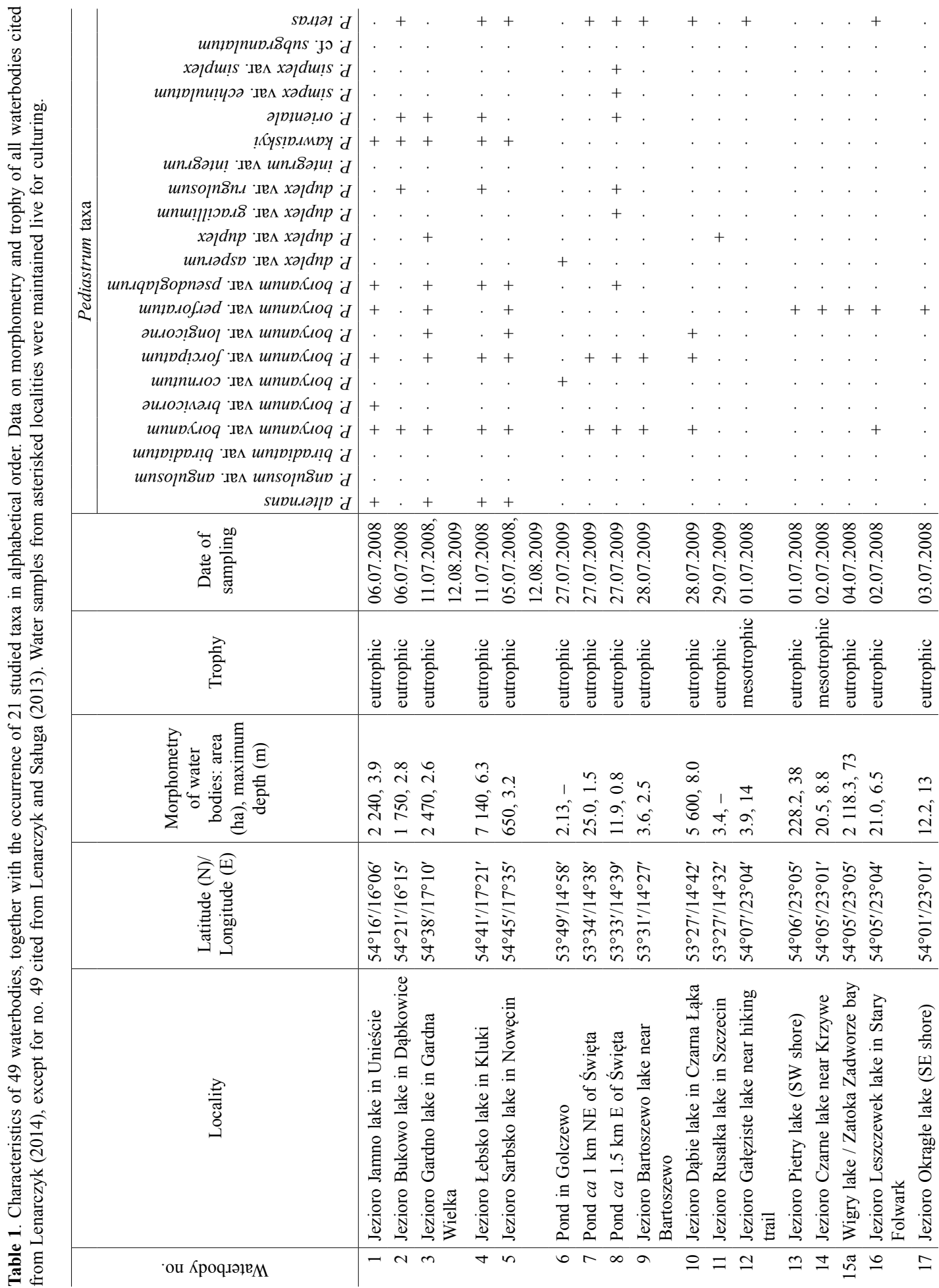




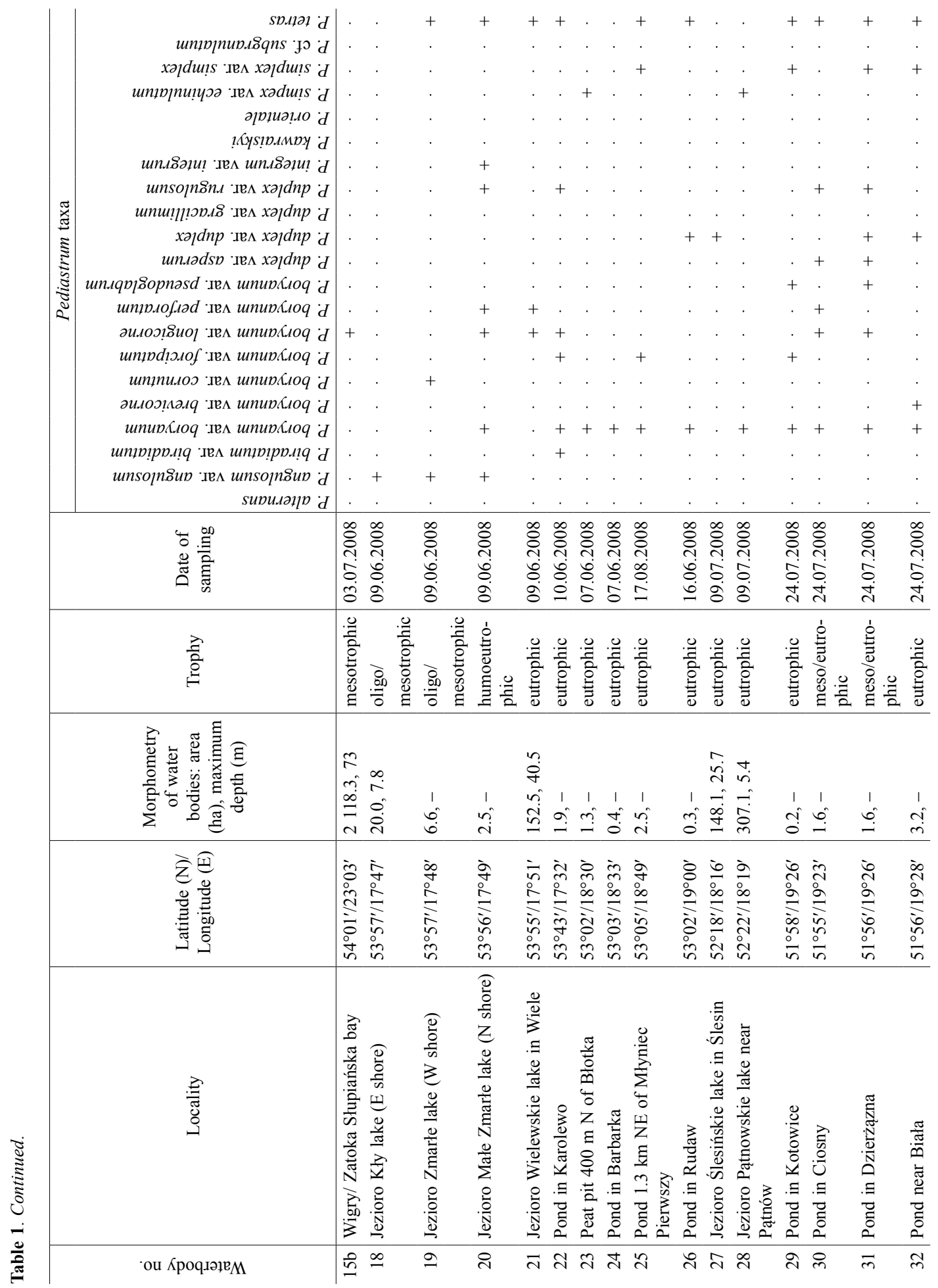




\begin{tabular}{|c|c|c|c|c|c|}
\hline 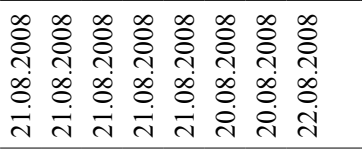 & $\begin{array}{l}\infty \\
\stackrel{8}{1} \\
\stackrel{1}{\infty} \\
\infty \\
\stackrel{i}{1}\end{array}$ & 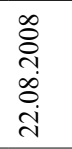 & 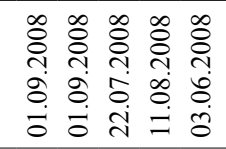 & 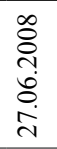 & $\begin{array}{l}\exists \\
\stackrel{1}{1} \\
\infty \\
0 \\
\ddot{i}\end{array}$ \\
\hline 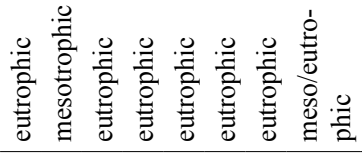 & 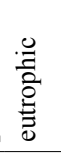 & 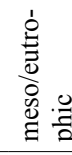 & 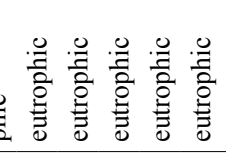 & 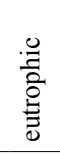 & 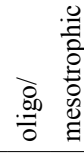 \\
\hline
\end{tabular}

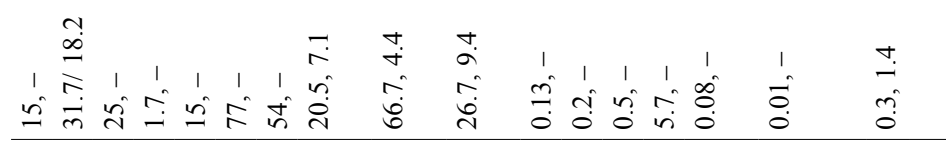

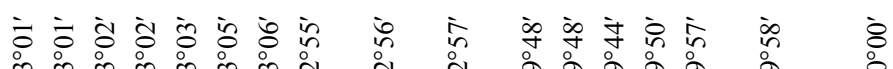
กิ

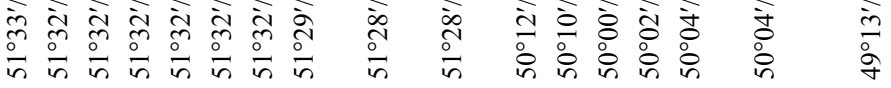

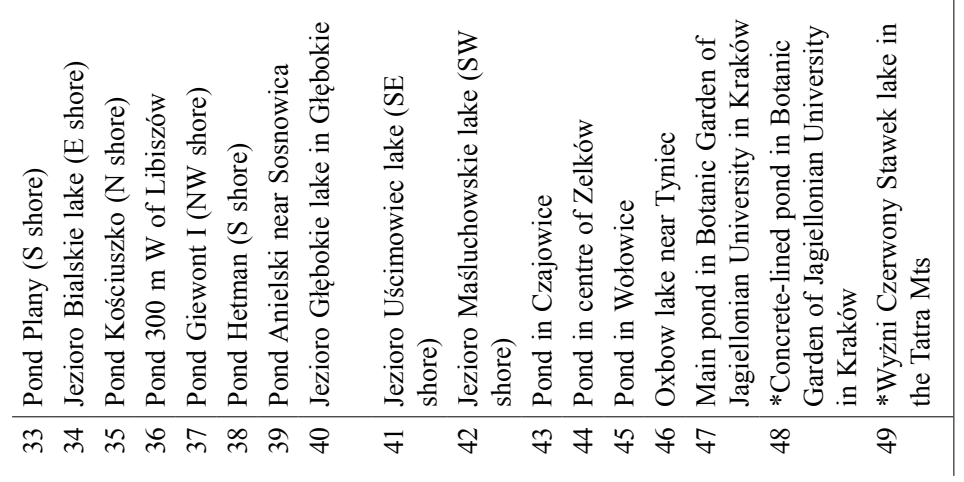


Table 2. Alphabetical list of cultured Pediastrum strains.

\begin{tabular}{|c|c|c|c|c|}
\hline No. & Taxon & Strain & Medium & Origin of isolated coenobia (water body no.) \\
\hline 1 & P. alternans & 01.160708 & Chu's and Knop's mixture & Jezioro Gardno lake in Gardna Wielka (3) \\
\hline 2 & P. biradiatum var. biradiatum & 02.040908 & Chu's & Pond Hetman (southern shore) (38) \\
\hline 3 & P. biradiatum var. biradiatum & 05.040908 & Chu's & Pond Hetman (southern shore) (38) \\
\hline 4 & P. boryanum var. brevicorne & 06.030608 & Chu's and Knop's mixture & $\begin{array}{l}\text { Concrete-lined pond in Botanic Garden of } \\
\text { Jagiellonian University in Kraków (48) }\end{array}$ \\
\hline 5 & P. boryanum var. cornutum & 19.090508 & Chu's & Jezioro Zatorek lake \\
\hline 6 & P. boryanum var. longicorne & $02.290811 \mathrm{a}$ & $\mathrm{L}-\mathrm{S}_{2} \mathrm{~T}_{2}$ & Wyżni Czerwony Stawek lake (49) \\
\hline 7 & P. boryanum var. longicorne & 13.280608 & Chu's and Knop's mixture & $\begin{array}{l}\text { Concrete-lined pond in Botanic Garden of } \\
\text { Jagiellonian University in Kraków (48) }\end{array}$ \\
\hline 8 & P. boryanum var. longicorne & 22.280608 & Chu's and Knop's mixture & $\begin{array}{l}\text { Concrete-lined pond in Botanic Garden of } \\
\text { Jagiellonian University in Kraków (48) }\end{array}$ \\
\hline 9 & P. duplex cf. var. duplex & 16.160708 & Chu's and Knop's mixture & Jezioro Jamno lake in Unieście (1) \\
\hline 10 & P. duplex var. rugulosum & 10.090508 & Chu's & Jezioro Zatorek lake \\
\hline 11 & P. duplex var. rugulosum & 13.090508 & Chu's and Knop's mixture & Jezioro Zatorek lake \\
\hline 12 & P. integrum var. integrum & 09.170408 & Chu's and Knop's mixture & Jezioro Warnowskie lake \\
\hline 13 & P. orientale & 12.160708 & Chu's and Knop's mixture & Jezioro Łebsko lake in Kluki (4) \\
\hline 14 & P. cf. subgranulatum & 19.300112 & $\mathrm{~S}_{2} \mathrm{~T}_{2}$ & Wyżni Czerwony Stawek Lake (49) \\
\hline
\end{tabular}

Table 3. Nine structural elements on the surface of coenobia in 21 analyzed Pediastrum taxa, and the states used in statistical analysis. $0-$ no, 1 - yes.

\begin{tabular}{|c|c|c|c|c|c|c|c|c|c|}
\hline Taxon & 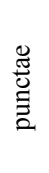 & 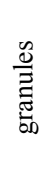 & 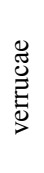 & 导 & 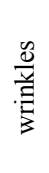 & $\begin{array}{l}\mathscr{d} \\
\stackrel{0}{0} \\
:\end{array}$ & 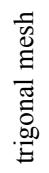 & 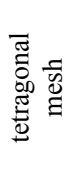 & 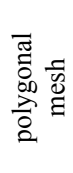 \\
\hline P. alternans & 0 & 0 & 1 & 0 & 1 & 0 & 0 & 0 & 0 \\
\hline P. angulosum var. angulosum & 0 & 0 & 0 & 0 & 0 & 1 & 0 & 0 & 0 \\
\hline P. biradiatum var. biradiatum & 0 & 1 & 0 & 0 & 1 & 0 & 0 & 0 & 0 \\
\hline P. boryanum var. boryanum & 0 & 1 & 0 & 0 & 0 & 0 & 1 & 0 & 0 \\
\hline P. boryanum var. brevicorne & 0 & 1 & 0 & 0 & 0 & 0 & 1 & 0 & 0 \\
\hline P. boryanum var. cornutum & 0 & 1 & 0 & 0 & 0 & 0 & 1 & 0 & 0 \\
\hline P. boryanum var. forcipatum & 1 & 1 & 0 & 0 & 0 & 0 & 0 & 0 & 0 \\
\hline P. boryanum var. longicorne & 0 & 1 & 0 & 0 & 0 & 0 & 1 & 0 & 1 \\
\hline P. boryanum var. perforatum & 0 & 1 & 0 & 0 & 0 & 0 & 1 & 0 & 0 \\
\hline P. boryanum var. pseudoglabrum & 1 & 1 & 1 & 0 & 0 & 0 & 0 & 0 & 0 \\
\hline P. duplex var. asperum & 0 & 0 & 0 & 0 & 0 & 1 & 0 & 0 & 0 \\
\hline P. duplex var. duplex & 0 & 0 & 0 & 0 & 0 & 0 & 0 & 0 & 0 \\
\hline P. duplex var. gracillimum & 0 & 0 & 0 & 0 & 0 & 0 & 0 & 0 & 0 \\
\hline P. duplex var. rugulosum & 0 & 1 & 0 & 0 & 0 & 0 & 0 & 0 & 1 \\
\hline P. integrum var. integrum & 0 & 1 & 0 & 0 & 0 & 0 & 1 & 0 & 1 \\
\hline P. kawraiskyi & 1 & 0 & 1 & 0 & 0 & 0 & 0 & 0 & 0 \\
\hline P. orientale & 0 & 1 & 0 & 0 & 1 & 0 & 0 & 0 & 0 \\
\hline P. simplex var. echinulatum & 0 & 0 & 0 & 1 & 0 & 0 & 1 & 1 & 0 \\
\hline P. simplex var. simplex & 0 & 1 & 0 & 0 & 0 & 0 & 1 & 0 & 1 \\
\hline P. cf. subgranulatum & 0 & 1 & 0 & 0 & 0 & 0 & 1 & 0 & 0 \\
\hline P. tetras & 0 & 0 & 0 & 0 & 0 & 0 & 0 & 0 & 0 \\
\hline
\end{tabular}


aldehyde was first rinsed with $10 \%$ ethanol $(3 \times 20 \mathrm{~min})$ and then dehydrated in a series of nine ethanol solutions increasing from $20 \%$ to $100 \%$ (20-30 min each) and finally in $100 \%$ acetone $(2 \times 30 \mathrm{~min})$. The material was placed in micropore capsules, critical-point dried with $\mathrm{CO}_{2}$ in an Anderson apparatus, and mounted on aluminum stubs with double-sided carbon tape. All the materials were sputter-coated with carbon or gold and viewed using Hitachi S-4700 or JEOL JSM 5410 scanning electron microscopes at the Institute of Geology and the Institute of Zoology of the Jagiellonian University, Kraków.

The nine structural elements observed on the surface of coenobia in 21 analyzed taxa and the states used in statistical analysis are given in Table 3. The wall patterns of Pediastrum taxa were compared by hierarchical clustering in Past ver. 2 (Hammer et al. 2001) and visualized as a classification dendrogram (Fig. 1). Clustering was based on Jaccard's coefficient and the UPGMA method. Morphological terminology follows Parra (1979) and Ziembińska-Tworzydło and KohlmanAdamska (2003). The classification system used here for Pediastrum follows Komárek and Jankovská (2001).

\section{RESULTS}

Depending on the occurrence or absence of ultrastructural elements, seven types of wall pattern were distinguished: (1) smooth, (2) scabrate, (3) granulate, (4) verrucate, (5) araneose, (6) rugulate, and (7) reticulate; they are described in Table 4. Rugulate ornamentation comprised two subtypes based on the elements situated on the wrinkles; reticulate ornamentation comprised three subtypes depending on the shape of mesh and the elements on it.

Most of the patterns were shared by at least two taxa. Three ornamentation types were represented by single taxa: granulate (3) by $P$. boryanum var. forcipatum (Corda) Chodat (Fig. 3a-h), verrucate (4) by P. kawraiskyi Schmidle (Figs $2 \& 3 \mathrm{i}-1$ ), and rugulate with verrucae $(6 \mathrm{~b})$ by $P$. alternans Nygaard (Fig. 5a-c) (Table 4, Fig. 1). There were some irregularities in the granulate wall pattern of $P$. boryanum var. forcipatum which made the pattern resemble the scabrate type (2) in P. boryanum var. pseudoglabrum Parra (Fig. $2 \mathrm{f}-\mathrm{k}$ ). The surface of $P$. boryanum var. pseudoglabrum was sometimes covered with short rows of granules, which made the pattern resemble the granulate type (3) in $P$. boryanum var. forcipatum. Besides the verrucate pattern (type 4) composed of large verrucae and punctae, an old coenobium of $P$. kawraiskyi (Fig. 21) exhibited scabrate-type (2) ornamentation composed of tiny verrucae and punctae, making the species most similar to $P$. boryanum var. pseudoglabrum and $P$. boryanum var. forcipatum in the classification diagram (Fig. 1). In contrast to P. kawraiskyi, P. alternans (Fig. 5a-c) had only one wall pattern, composed of wrinkles and verrucae (type $6 \mathrm{~b}$ ), which was not shared with other species. Pediastrum alternans formed one clade with $P$. biradiatum var. biradiatum (Fig. $4 \mathrm{k}-1$ ) and P. orientale (Fig. $4 \mathrm{~g}-\mathrm{j}$ ), because the three taxa were covered with wrinkles (Table 3, Fig. 1).

The reticulate pattern with a trigonal mesh and granules (type 7c) was shared by the highest number of taxa (8), mostly P. boryanum varieties. The density and size of granules, as well as the shape of the mesh, differed between and within some $P$. boryanum varieties. The densest granulation, up to 18-20 granules per cell width, was observed in P. boryanum var. boryanum (Fig. 6b) and P. boryanum var. brevicorne A. Braun (Fig. 6c), and the least dense (6-7 granules per cell width) in P. boryanum var. boryanum, $P$. boryanum var. longicorne Reinsch (Fig. 6d-f) and P. boryanum var. perforatum (Racib.) Nitardy (Fig. 6i). Granule density was a stable feature in $P$. boryanum var. longicorne, but SEM revealed differences in the shape of granules and mesh between cultures from different localities. The granules were delicate and the mesh trigonal in coenobia from lowland waters (Fig. 6d, e), but the granules were prominent and rounded, and the mesh polygonal or trigonal, in a strain from Wyżni Czerwony Stawek lake in the Tatra Mountains (Fig. 6f).

Similarly to $P$. boryanum, $P$. simplex Meyen varieties were also covered with mesh and additional elements. Pediastrum simplex var. echinulatum Wittr. was covered with spines disposed on a trigonal or tetragonal mesh (type 7b; Figs 1 $\& 5 \mathrm{~h}-\mathrm{k})$. However, the differences between the spines of this variety and the granules of $P$. simplex var. simplex (Fig. 61) were so slight in some cells that it was difficult to distinguish the two taxa. 

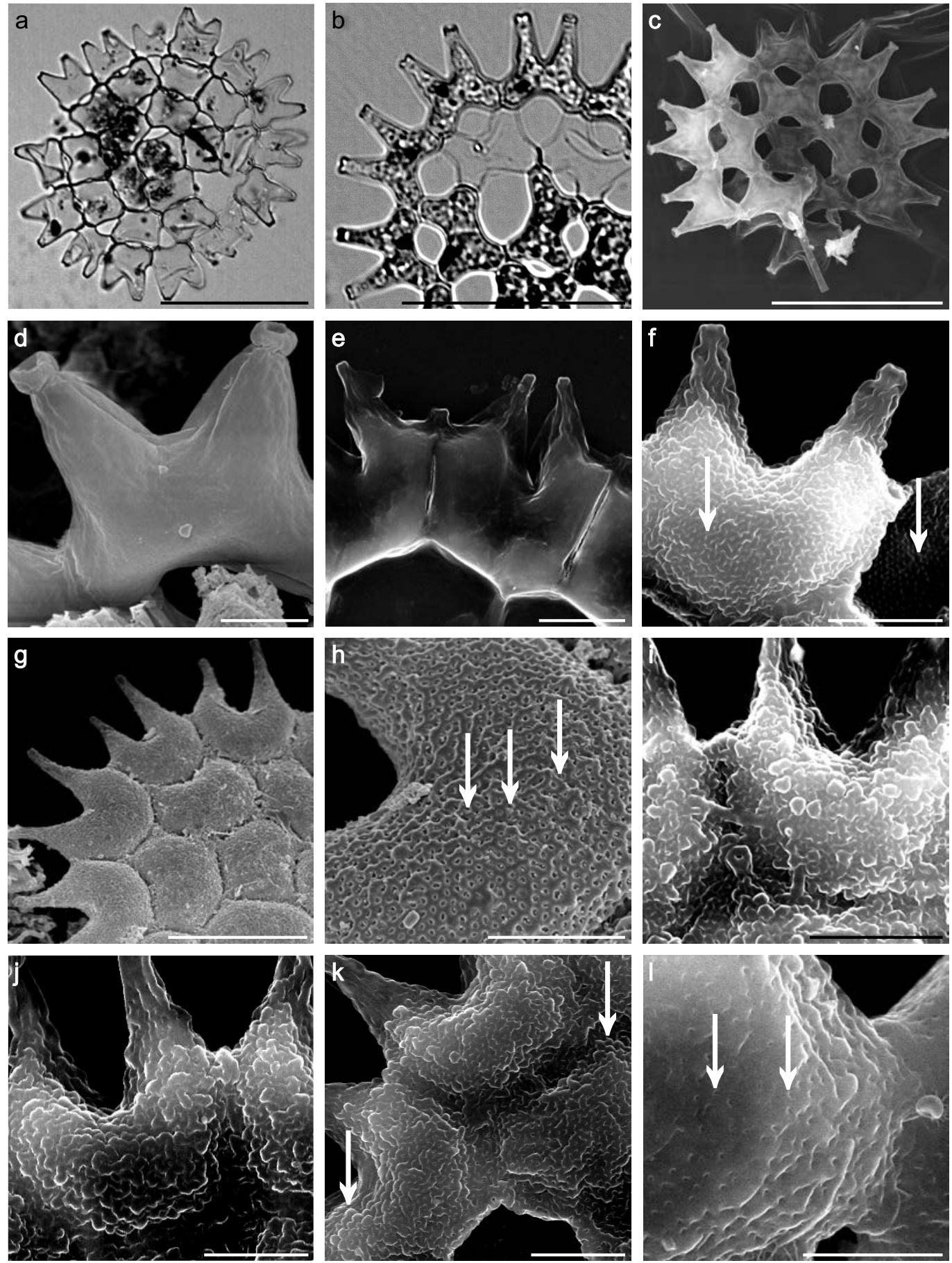

Fig. 2. Cell wall surface in Pediastrum Meyen: smooth (a-e) and scabrate (f-1). a, c, d-P. duplex Meyen var. duplex, b - P. duplex cf. var. duplex, e - P. tetras (Ehrenb.) Ralfs, $\mathrm{f}-\mathrm{k}-$ P. boryanum var. pseudoglabrum (Turpin) Menegh., $1-$ P. kawraiskyi Schmidle. Arrows - punctae (f, h, l) or rows of granules (k). Scale bars: a-c $-40 \mu \mathrm{m} ; \mathrm{g}-20 \mu \mathrm{m} ; \mathrm{d}-\mathrm{f}, \mathrm{h}-1-5 \mu \mathrm{m}$. 

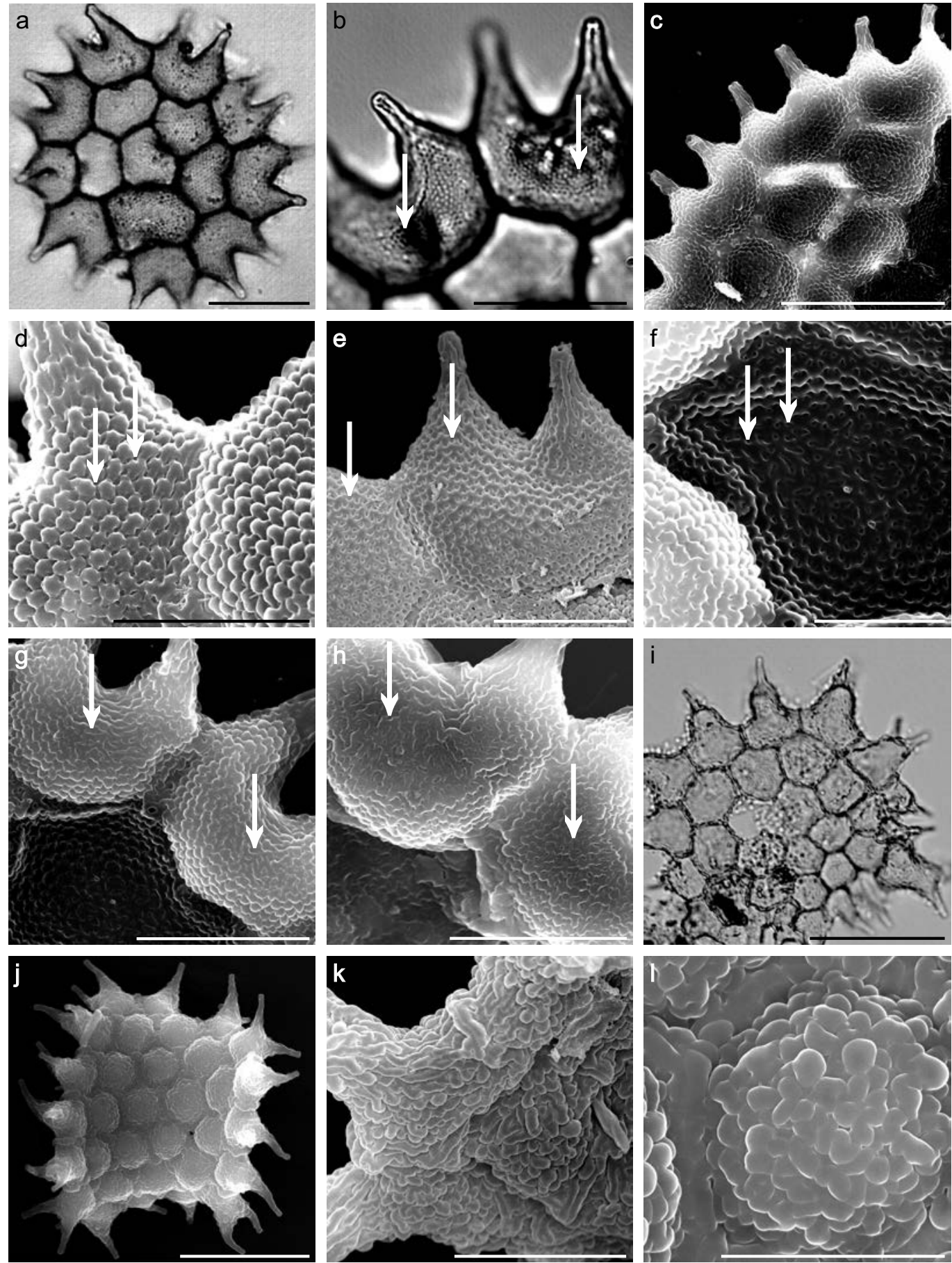

Fig. 3. Cell wall surface in Pediastrum Meyen: granulate (a-h) and verrucate (i-1). a-h $-P$. boryanum var. forcipatum (Corda) Chodat, i-1 - P. kawraiskyi Schmidle. Arrows - granules (b), punctae (d-f) or deviations of cell wall (g, h). Scale bars: a, i $-40 \mu \mathrm{m}$; b, c, j- $20 \mu \mathrm{m} ; \mathrm{e}, \mathrm{g}, \mathrm{h}, \mathrm{k}-10 \mu \mathrm{m} ; \mathrm{d}, \mathrm{f}, 1-5 \mu \mathrm{m}$. 

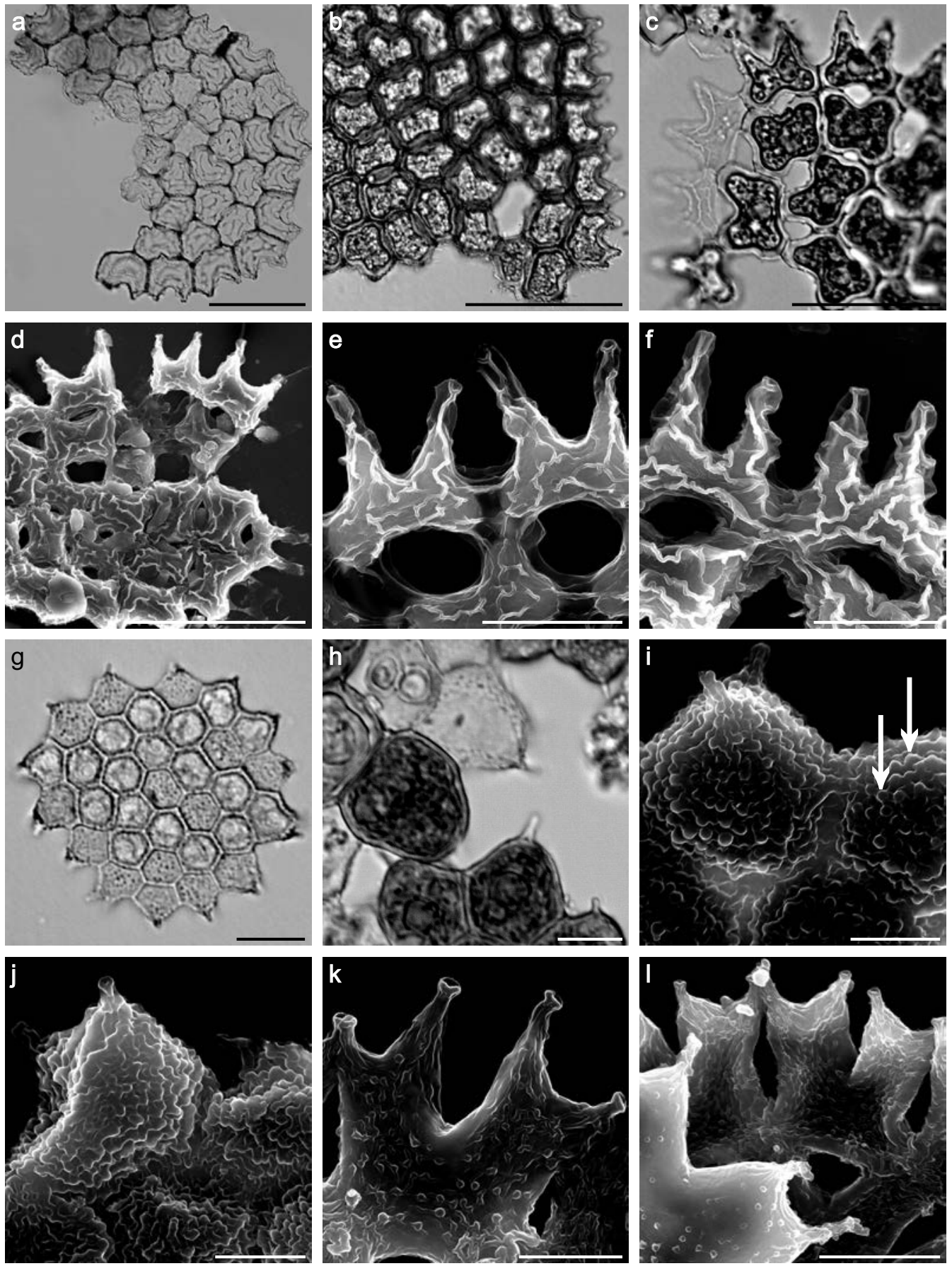

Fig. 4. Cell wall surface in Pediastrum Meyen: araneose (a-f) and rugulate with granules ( $\mathrm{g}-1)$. a \& $\mathrm{b}-$ P. angulosum (Ehrenb.) Menegh. var. angulosum, $\mathrm{c}-\mathrm{f}-$ P. duplex var. asperum (A. Braun) Hansg., g-j - P. orientale (Skuja) Jankovská \& Komárek, $\mathrm{k} \& 1-$ P. biradiatum Meyen var. biradiatum. Arrows - granules (i). Scale bars: a, b $-60 \mu \mathrm{m} ; \mathrm{c}, \mathrm{d}-40 \mu \mathrm{m}, \mathrm{e}-\mathrm{h} ; 1-10 \mu \mathrm{m}$; $\mathrm{i}-\mathrm{k}-5 \mu \mathrm{m}$. 

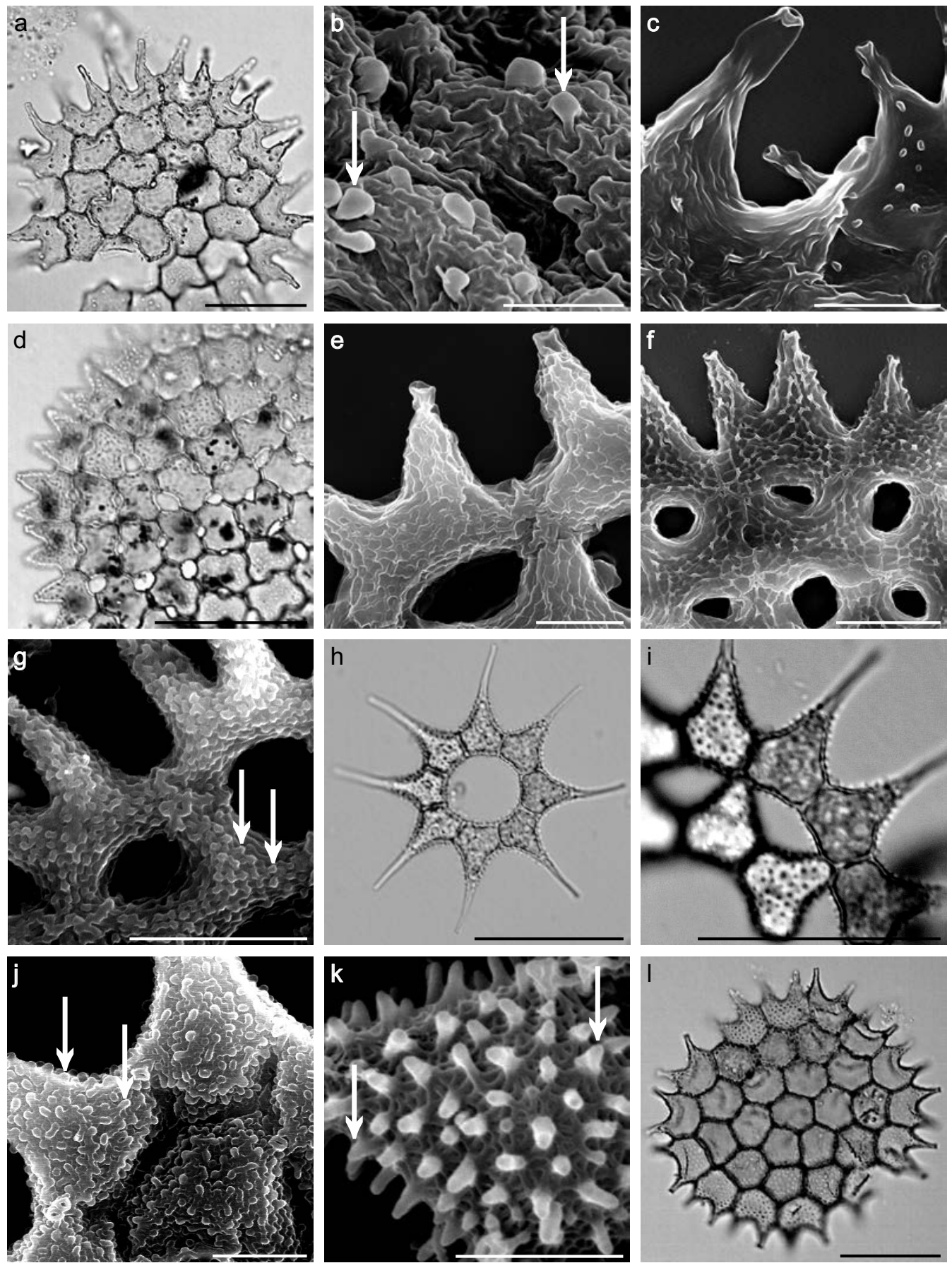

Fig. 5. Cell wall surface in Pediastrum Meyen: rugulate with verrucae (a-c), reticulate with granules on polygonal mesh $(\mathrm{d}-\mathrm{g})$, reticulate with spines on trigonal or tetragonal mesh $(\mathrm{h}-\mathrm{k})$, and reticulate with granules on trigonal mesh (l). a-c $-P$. alternans Nygaard, $\mathrm{d}-\mathrm{g}-$ P. duplex var. rugulosum Racib., $\mathrm{h}-\mathrm{k}-$ P. simplex var. echinulatum Wittr., $1-$ P. boryanum (Turpin) Menegh. var.

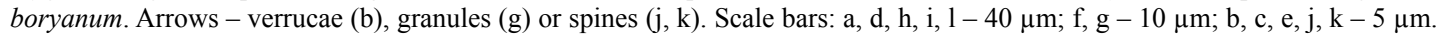



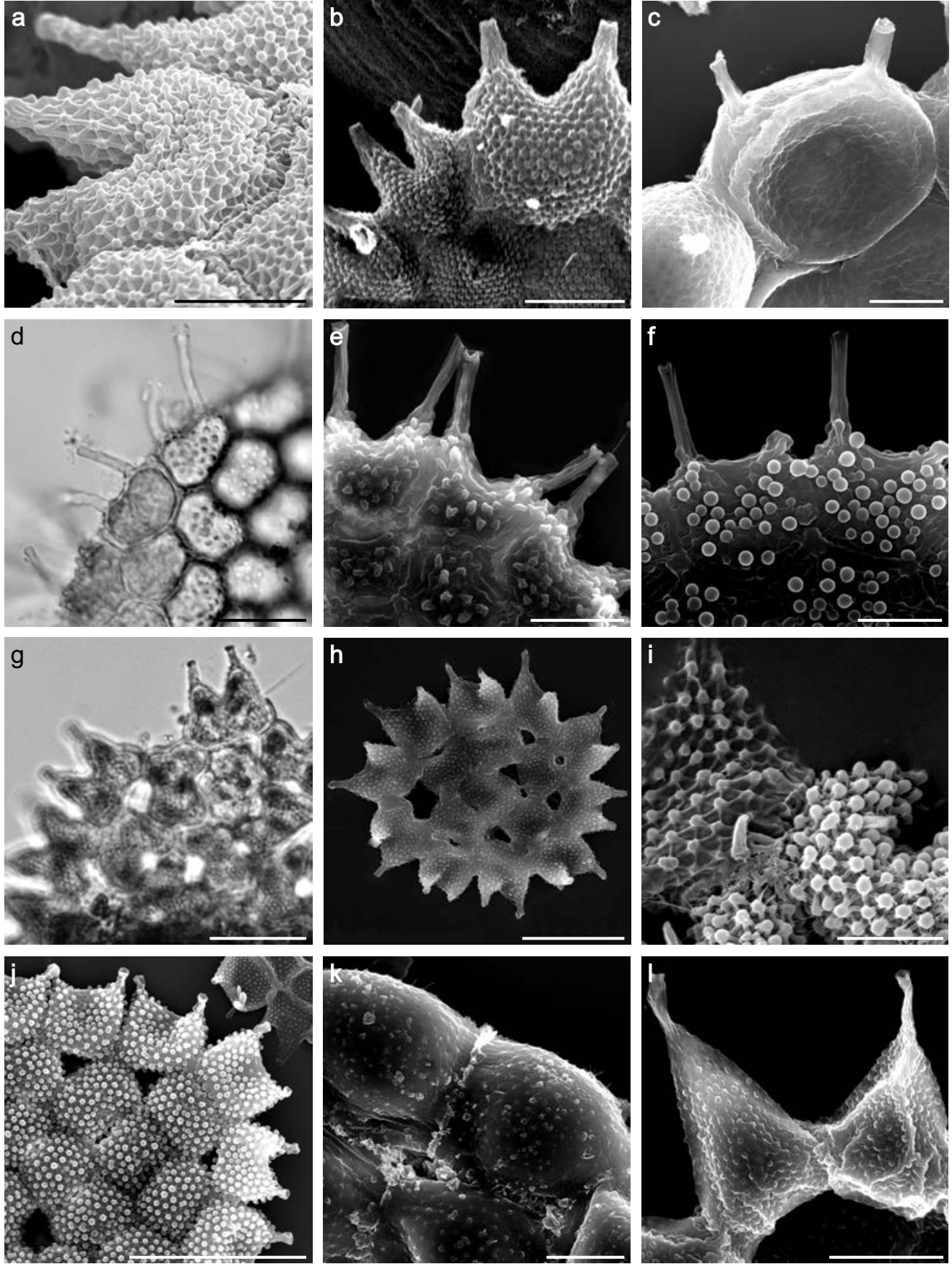

Fig. 6. Wall surface: reticulate with granules on trigonal mesh, in Pediastrum Meyen. a - P. boryanum (Turpin) Menegh. cf. var. boryanum, $\mathrm{b}-P$. boryanum var. boryanum, $\mathrm{c}-$ P. boryanum var. brevicorne A. Braun, $\mathrm{d}-\mathrm{f}-P$. boryanum var. longicorne Reinsch, g \& h - P. boryanum var. cornutum (Racib.) Sulek, i - P. boryanum var. perforatum (Racib.) Nitardy, $\mathrm{j}-$ P. cf. subgranulatum (Racib.) Jankovská \& Komárek, $\mathrm{k}-$ P. integrum Nägeli var. integrum, $1-P$. simplex Meyen var. simplex. Scale bars: $\mathrm{d}, \mathrm{g}, \mathrm{h}, \mathrm{j}-20 \mu \mathrm{m}$; e, k, $1-10 \mu \mathrm{m}$; a-c, f, i - $5 \mu \mathrm{m}$. 


\section{DiscuSSION}

Among the 21 taxa investigated, only Pediastrum alternans (Fig. 5a-c) is characterized by a single wall pattern - rugulate with verrucae (type $6 \mathrm{~b}$ ) - not shared with other taxa (Table 4, Fig. 1). It follows that this pattern is a reliable diagnostic character for the species. Kowalska and Wołowski (2010b) proposed verrucae as a new taxonomical character for P. alternans, since Nygaard (1949) did not mention it in the original description.

In our analysis the wall pattern of $P$. alternans proved to be most similar to that of $P$. biradiatum var. biradiatum (Fig. 4k-1) and P. orientale (Fig. $4 \mathrm{~g}-\mathrm{j}$ ) in the classification dendrogram (Fig. 1). These three taxa have wrinkles on their surface, but with different additional elements: verrucae in $P$. alternans and granules in the other two. The three taxa are not morphologically similar (Lenarczyk 2014). No molecular data on $P$. orientale have been published so far, but some of our preliminary data indicate that $P$. alternans forms a clade with $P$. boryanum strains. This means that the similarities in wall ultrastructure in $P$. alternans, $P$. biradiatum var. biradiatum and $P$. orientale could have arisen independently in their evolution.

Our description of the wall surface in $P$. orientale differs from those given by other authors. Komárek and Jankovská (2001) described its ornamentation as a mesh with granules, Sulek (1969) as rugulate with tiny depressions, and Nygaard (1977) as covered with pores in oblique decussate series. The differences between the descriptions may be connected with a taxonomical problem in $P$. orientale pointed out by Kowalska and Wołowski (2010b). Based on the variability of wall surface and cell shape, Kowalska and Wołowski (2010b) suggested that $P$. orientale is a complex taxon composed of several similar species. Further studies comparing the morphology and phylogenetic relations of its monoclonal strains are needed to address the taxonomical problem; until it is resolved, wall ornamentation cannot be regarded as a diagnostic character in $P$. orientale.

The variability of the reticulate pattern with granules disposed regularly on a trigonal mesh (type 7c) is so great that this pattern has little diagnostic value for Pediastrum taxa. Pediastrum boryanum var. boryanum (Fig. 6b), with its wide range of granule density, is a good example of that variability. Lenarczyk (2015) stated that granule density within a single $P$. boryanum var. boryanum strain does not change significantly when cultured at different nutrient concentrations, but in preliminary studies, McManus and Lewis (2005) found that the nutrient status of the culture medium influences phenotypic variability in a strain with $P$. boryanum-like morphology, including granule density. In our present study we found that granule density in $P$. boryanum var. brevicorne (Fig. 6c) was within the range of $P$. boryanum var. boryanum (Fig. 6b). According to Komárek and Jankovská (2001), these varieties differ from each other in the length of processes and the depth of marginal cell incisions, but Nielsen (2000) stated that the variety brevicorne should be rejected and

Table 4. Types of wall surface in Pediastrum taxa noted in the present study.

\begin{tabular}{cll}
\hline Type & Wall pattern & Description \\
\hline 1 & smooth & without any concave or convex elements (Fig. 2a-e) \\
2 & scabrate & tiny verrucae and punctae, exceptionally short rows of granules (Fig. 2f-1) \\
3 & granulate & granules in regular rows and punctae (Fig. 3a-h) \\
4 & verrucate & verrucae or verrucae and punctae (Fig. 3i-1) \\
5 & araneose & ridges lying irregularly (Fig. 4a-f) \\
6 & rugulate & a winkles with granules (Fig. 4g-1) \\
& & b winkles with verrucae (Fig. 5a-c) \\
7 & reticulate & a granules on a polygonal mesh (Fig. 5d-g) \\
& & b spines on a trigonal or tetragonal mesh (Fig. 5h-k) \\
& & c granules on a trigonal mesh (Figs 5l, 6a-1) \\
\hline
\end{tabular}


included into the nominate variety, as their cell shape varies depending on ontogeny and there is no difference in granule density. Therefore density should not be regarded as a diagnostic character for the variety brevicorne. We also found that the coenobia of $P$. boryanum var. cornutum (Racib.) Sulek (Fig. 6g, h) and P. boryanum var. perforatum (Fig. 6i) are similar in granule density and in coenobium shape and cell shape. This supports Nielsen's (2000) doubts about the distinction between these varieties.

Some preliminary data (Lenarczyk \& Saługa 2013) indicate that in the phylogenetic tree the strain P. boryanum var. longicorne isolated from mountains (Table 2, no. 6) is not closely related to two other strains of $P$. boryanum var. longicorne isolated from lowland (Table 2, nos 7 and 8). That suggestion is supported by morphological differences between the lowland and mountain strains we observed in the present study. The variety longicorne is a complex taxon.

The taxonomical position of $P$. boryanum var. pseudoglabrum (Fig. 2i-h) and P. boryanum var. forcipatum (Fig. 3a-h) is questionable as well, in view of their similar cell shape and deviations from the scabrate (type 2) and granulate (type 3) wall patterns. According to Lenarczyk (2014), P. boryanum var. pseudoglabrum probably is $P$. boryanum var. forcipatum with not well developed granulate ornamentation.

To distinguish between $P$. simplex var. simplex (Fig. 61) covered with granules and $P$. simplex var. echinulatum (Fig. 5h-k) covered with spines, and to identify the range of spine length in the latter variety from field material, analysis of these features in monoclonal cultures is necessary. By that method the length of structural elements, spines and granules can be measured in specimens unambiguously representing individual $P$. simplex genotypes. Parra (1979) and Wu (1987) did not distinguish the variety echinulatum, but determined $P$. simplex coenobia with spines as $P$. simplex var. simplex. McManus and Lewis (2011) genetically analyzed single strains of $P$. simplex var. simplex [as Monactinus simplex var. simplex (Meyen) Corda] and P. simplex var. echinulatum [as M. simplex var. echinulatum (Wittr.) H. McManus \& L. A.
Lewis]; the two strains differed only slightly in their 26S rDNA and rbcL sequences.

We also observed some wall features differing from those given in the literature as characteristic for $P$. simplex var. simplex, $P$. duplex var. rugulosum Racib., P. tetras (Ehrenb.) Ralfs and $P$. duplex var. duplex. In $P$. simplex var. simplex (Fig. 61) the granules were disposed regularly on a trigonal mesh (type 7c), irregularly on a polygonal mesh (type 7a), but not on wrinkles as stated by Komárek and Jankovská (2001). According to Parra (1979), trigonal mesh occurs in younger specimens and then turns into an irregular pattern whose elements are similar to wrinkles building Y-shaped connections. Besides the reticulate ornamentation in P. simplex var. simplex, Parra (1979) observed fossulate ornamentation in his newly described $P$. simplex var. pseudoglabrum.

In $P$. duplex var. rugulosum the granules were of different sizes (Fig. $5 \mathrm{~d}-\mathrm{g}$ ). The bigger ones covered the mesh or wrinkles to which they were affixed (Fig. 5g). Hindák and Hindáková (2008) may also have observed coenobia with such granules, as they stated that the surface of this taxon is covered with granules, not reticulate with granules (type 7a).

The single coenobium of $P$. tetras observed by SEM (Fig. 2e) was smooth with sparse sites of roughness resembling granules or verrucae. Parra (1979) noted various ornamentation types in this species: irregularly granulate, reticulate, and rugulate with granules. Shubert and WilkWoźniak (2003) found a rugulate coenobium in a waterbody in Puławy, central Poland. Wu (1987) distinguished $P$. tetras var. tetras with a reticulate pattern and $P$. tetras var. tetraodon (Corda) Hansg. with a granulate one. McManus and Lewis (2005) observed a rugulate/reticulate surface in different strains of $P$. tetras from Europe and North America, and thick wrinkles in another strain from North America. Komárek and Jankovská (2001) and McManus and Lewis (2005) indicated that strains with $P$. tetras-like morphology may represent separate taxa.

A smooth surface (type 1) was observed in two P. duplex varieties: P. duplex var. duplex (Fig. 2a, c, d) and P. duplex var. gracillimum. Due 
to the shared surface type, Sulek (1969) and Parra (1979) proposed that the latter variety should be included into the nominate one. However, McManus et al. (2011) used molecular and morphometric methods to describe a new genus Lacunastrum H. McManus and a new combination L. gracillimum (W. \& G. S. West) H. McManus (formerly P. duplex var. gracillimum).

We observed the last type of wall surface araneose (type 5) - in two varieties from different species: P. angulosum (Ehrenb.) Menegh. var. angulosum (Fig. 4a, b) and P. duplex var. asperum (A. Braun) Hansg. (Fig. 4c-f). McManus and Lewis (2011) reported phylogenetic results based on a single strain of $P$. duplex var. asperum and seven strains of $P$. angulosum, which were grouped in two different clades consisting mainly of $P$. $d u$ plex, not assigned names to variety level. Thus, it seems likely that araneose ornamentation evolved independently in various Pediastrum lineages.

In addition to differences in wall patterns between taxa, our SEM study of cultured material disclosed changes in wall patterns during coenobium growth and aging. In older specimens the reticulum and wrinkles were flatter, poorly visible and delicate, and the granules and verrucae were disposed more sparsely (Figs 41 \& 6k). Such changes, resulting from wall stretching, were also reported by Hegewald and Yamagishi (1994). We also showed that the verrucate pattern can become scabrate as a result of wall stretching and flattening of verrucae during coenobium growth. According to Sulek (1969) and Parra (1979), each ornamentation type in Pediastrum is variable within a certain range, depending on the ontogenetic cycle and cell size. It should be stressed that the changes in wall patterns connected with the ontogenetic cycle or cell size are poorly recognized so far.

We found great phenotypic variability in the examined Pediastrum taxa from Polish waterbodies, especially within $P$. boryanum. We conclude that ultrastructural features cannot be used as a diagnostic tool for most taxa of the genus, but that those characters can be helpful in identifying certain taxa when they are found in similar environmental conditions, and therefore are of some value. The challenge for the future is to discover the full range of wall variability in individual taxa throughout their life cycle, and to determine the impact of particular environmental factors more precisely.

Acknowledgements. We thank Professor Brian A. Whitton and Michael Jacobs for reviewing the English, the anonymous reviewers for helpful remarks and suggestions on the manuscript, and Professor Lubomira Burchardt for the water samples from Jezioro Warnowskie lake and Jezioro Zatorek lake used to initiate some of the Pediastrum cultures. The study was funded in part by the Polish Ministry of Science and Higher Education for 2008-2010 (grant no. N N303 070534) and by the statutory fund of the W. Szafer Institute of Botany, Polish Academy of Sciences, including in-house grants for young scientists in 2012 and 2015.

\section{REFERENCES}

An S. S., Hegewald E. \& Jeon S. L. 1999. Pediastrum privum (Printz) Hegewald new to Korea. Algae 14: 83-85.

Buchheim M., Buchheim J., Carlson T., Braband A., Hepperle D., Krienitz L., Wolf M. \& Hegewald E. 2005. Phylogeny of the Hydrodictyaceae (Chlorophyceae): inferences from rDNA data. J. Phycol. 41: 1039-1054.

Couté A. \& Tell G. 1979. Ultrastructure de la paroi de quatre espèces de Pediastrum Meyen (Chlorococcales, Hydrodictyaceae). Bull. Mus. Natl. Hist. Nat. 4B1: 97-105.

Gawlik S. R. \& MiLlington W. F. 1969. Pattern formation and the fine structure of the developing cell wall in colonies of Pediastrum boryanum. Amer. J. Bot. 56: 1084-1096.

Hammer O., Harper D. A. T. \& Ryan P. D. 2001. PAST: Paleontological statistics software package for education and data analysis. Palaeontologia Electronica 4: 1-9.

Hegewald E. \& JeON S. L. 2000. The coenobial morphology of Pediastrum privum (Printz) Hegewald. Algol. Stud. 98: 43-48.

Hegewald E. \& Yamagishi T. 1994. Pediastrum asymmetricum Yamagishi et Hegewald a new species from Japan and some notes on accompanying taxa. Nova Hedwigia 59: 77-95.

Hindák F. \& Hindákové A. 2008. Morphology and taxonomy of some rare chlorococcalean algae (Chlorophyta). Biologia 63: $777-786$.

Jena M., Bock C., Behera C., Siba P., Adhikary S. P. \& KrieNITZ L. 2014. Strain survey on three continents confirms the polyphyly of the genus Pediastrum (Hydrodictyaceae, Chlorophyceae). Fottea 14: 63-76.

KomÁrek J. \& JANKovská V. 2001. Review of the green algal genus Pediastrum: implication for pollen-analytical research. Biblioth. Phycol. 108: 1-127. 
Kowalska J. \& Wolowski K. 2010a. Pediastrum privum (Printz) Hegewald (Chlorophyceae) in Lake Małe Zmarłe, northern Poland. Oceanological and Hydrobiological Studies 39: 137-43.

KowalsKa J. \& WolowsKi K. 2010b. Rare Pediastrum species (Chlorophyceae) from Polish coastal lakes. Acta Soc. Bot. Poloniae 79: 225-233.

LANG P., Krokowski J. \& Ross N. 2012. The rare green alga Pediastrum privum (Chlorophyta, Sphaeropleales) in a Scottish kettle loch: new to British freshwaters. Glasgow Naturalist 25(4): 139-142.

LenarczyK J. 2014. The algal genus Pediastrum Meyen (Chlorophyta) in Poland. W. Szafer Institute of Botany, Polish Academy of Sciences, Kraków.

LENARCZYK J. 2015. Morphological plasticity of the microscopic green alga Pseudopediastrum boryanum (Chlorophyceae) under varying nutrient concentrations. Nova Hedwigia. DOI: 10.1127/nova hedwigia/2015/0314

LenarczyK J. \& Saluga M. 2013. What do classical taxonomy and molecular data reveal about diversity of Pediastrum taxa in the Western Carpathians? Preliminary results. Acta Biol. Cracov., Ser. Bot. 55: 54.

Marchant H. J. 1974. Mitosis, cytokinesis and colony formation in Pediastrum boryanum. Ann. Bot. 38: 883-888.

McManus H. A. \& Lewis L. A. 2005. Molecular phylogenetics, morphological variation and colony-form evolution in the family Hydrodictyaceae (Sphaeropleales, Chlorophyta). Phycologia 44: 582-595.

McManus H. A. \& Lewis L. A. 2011. Molecular phylogenetic relationships in the freshwater family Hydrodictyaceae (Sphaeropleales, Chlorophyceae), with an emphasis on Pediastrum duplex. J. Phycol. 47: 152-163.

McManus H. A., Lewis L. A. \& Schultz E. T. 2011. Distinguishing multiple lineages of Pediastrum duplex with morphometrics and a proposal for Lacunastrum gen. nov. J. Phycol. 47: 123-130.
Millington W. F., Chubb G. T. \& Seed Th. M. 1981. Cell shape in the alga Pediastrum (Hydrodictyaceae; Chlorophyta). Protoplasma 105: 169-176.

Millington W. F. \& Gawlik S. R. 1970. Ultrastructure and initiation of wall pattern in Pediastrum boryanum. Amer. J. Bot. 57: 552-561.

NielSEN H. 2000. Morphometric analysis of cell wall sculpture in seven infraspecific taxa of Pediastrum boryanum (Sphaeropleales, Chlorophyta) and its taxonomic implications. Phycologia 39: 36-49.

NygaARD G. 1949. Hydrobiological studies on some Danish ponds and lakes. Part II: The quotient hypothesis and some new or little known phytoplankton organisms. Kongel. Danske Vidensk. Selsk. Biol. Skr. 7: 1-293.

NyGAARD G. 1977. New or interesting plankton algae with a contribution on their ecology. Kongel. Danske Vidensk. Selsk. Biol. Skr. 21(1): 1-107.

Parra O. O. 1979. Revision der Gattung Pediastrum Meyen (Chlorophyta). Biblioth. Phycol. 48: 1-186.

Shubert E. \& Wilk-WoźNIAK E. 2003. SEM investigation of several non-motile coccoid green algae isolated from aquatic habitats in Poland. Biologia 58: 459-466.

Starmach K. 1963. Flora slodkowodna Polski. 1. Rośliny słodkowodne. Wstęp ogólny i zarys metod badania. Polska Akademia Nauk, Instytut Botaniki, Państwowe Wydawnictwo Naukowe, Warszawa.

Sulek J. 1969. Taxonomische Übersicht der Gattung Pediastrum Meyen. In: B. Fotт (ed.), Studies in Phycology, pp. 197-261. Publishing House of the Czechoslovak Academy of Sciences, Prague.

Wu J.-T. 1987. Revision of Formosan Pediastrum. Nova Hedwigia 44: 497-508.

ZiembińSKa-TworzydŁo M. \& KoHLMAN-AdAMSKA A. 2003. Morfologia. In: S. DyBova-JACHOWICZ \& A. SADOWSKA (eds), Palinologia, pp. 33-53. Wydawnictwa Instytutu Botaniki PAN, Kraków. 